\title{
CrimRxiv
}

\section{Access Denied The Practice and Policy of Global Internet Filtering}

Ronald Deibert, John Palfrey, Rafal Rohozinski, Jonathan L. Zittrain

Published on: Mar 04, 2022

License: Creative Commons Attribution 4.0 International License (CC-BY 4.0). 
